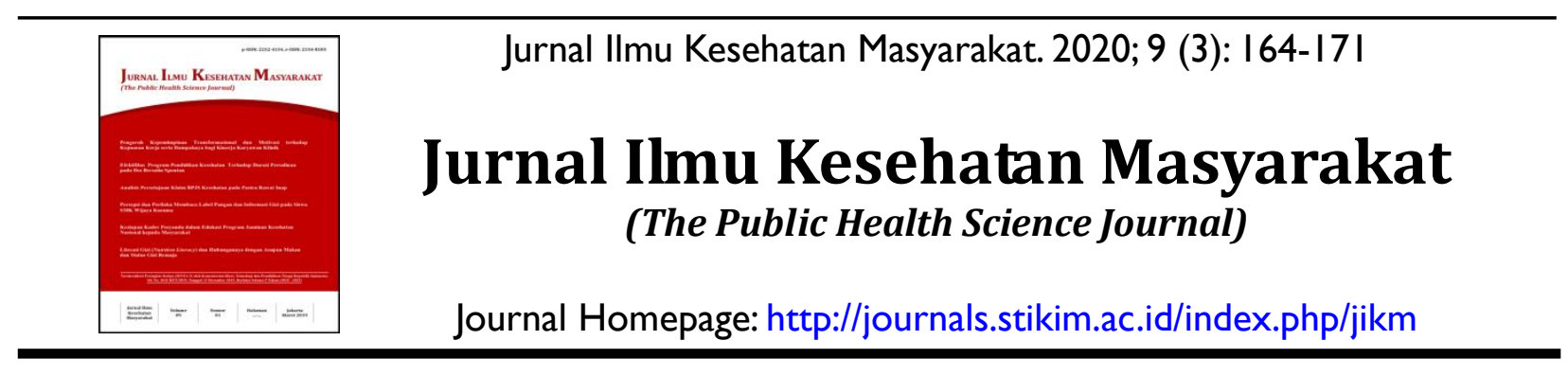

\title{
Peningkatan Kemampuan Remaja Menghindari HIV/AIDS Melalui Pelatihan Keterampilan Hidup
}

\author{
Mia Fatma Ekasari ${ }^{1}$, Rosidawati ${ }^{2}$, Ahmad Jubaedi ${ }^{3}$ \\ 1,2Poltekkes Kemenkes Jakarta III, JI. Arteri JORR Pondok Melati, Jatiwarna, Bekasi \\ 3 Universitas Faletehan, Jl. Raya Cilegon KM 6, Pelamunan, Kramatwatu, Serang \\ Email : miafatma74@gmail.com', rosida1962@yahoo.co.id², ahmadjoe@gmail.com³
}

\begin{abstract}
Abstrak
Perubahan fisik yang pesat dan perubahan hormonal merupakan pemicu masalah kesehatan remaja yang serius. Timbulnya dorongan motivasi seksual yang tinggi menjadikan remaja rawan terhadap berbagai masalah kesehatan reproduksi seperti Penyakit Menular Seksual (PMS) dan HIVIAIDS. Penelitian ini bertujuan untuk mendapat gambaran pengaruh latihan keterampilan hidup terhadap kemampuan remaja dalam menghindari HIVIAIDS. Penelitian ini dilakukan di dua SMPN di wilayah Cipayung, Jakarta Timur dengan responden siswa/i yang berumur I2-I5 tahun. Penelitian ini menggunakan metodologi quasi experiment with control group design. Pengumpulan data dilakukan dengan menggunakan kuesioner. Pada kelompok intervensi diberikan latihan dengan menggunakan modul dan buku catatan harian sebanyak 8 kali. Hasil penelitian menunjukkan bahwa terdapat perbedaan yang signifikan rata-rata pengetahuan (6,55 vs 8,9I; $P v=0,000)$, sikap (7,24 vs 8,9I; $P v=0,000)$, dan keterampilan $(29,79$ vs 34,$67 ; P v=0,000)$ antara kelompok intervensi dan kontrol, sebelum dan setelah diberikan intervensi. Pelatihan keterampilan hidup remaja dapat digunakan sebagai salahsatu intervensi dalam praktik keperawatan dalam upaya mencegah HIV AIDS pada remaja.
\end{abstract}

Kata Kunci : HIVIAIDS, keterampilan hidup, remaja

\begin{abstract}
Rapid physical changes and hormonal changes are a trigger for serious adolescent health problems. The emergence of a high sexual motivation drive makes adolescents vulnerable to various reproductive health problems such as sexually transmitted diseases (STDs) and HIVIAIDS. This study aims to get an idea of the effect of life skills training on adolescent's ability to avoid HIVIAIDS. This research was conducted in two junior high schools in the Cipayung region, East Jakarta with student respondents aged I 2-I 5 years old. This research uses a quasi experiment with control group design methodology. Data collection was carried out using a questionnaire. The intervention group was given training using a module and a diary 8 times. The results showed that there were significant differences in the mean knowledge (6.55 vs 8.9I;Pv =0.00I), attitudes $(7.24 \mathrm{vs} 8.9 \mathrm{I} ; P v=0.00 \mathrm{I})$, and skills $(29.79$ vs 34,$67 ; P v=0.001)$ between the intervention and control groups, before and after the intervention was given. Youth life skills training can be used as an intervention in nursing practice in an effort to prevent HIV AIDS in adolescents.
\end{abstract}

Keywords: HIVIAIDS, life skills, adolescent 


\section{Pendahuluan}

Remaja merupakan kelompok penduduk Indonesia dengan jumlah yang cukup besar, dimana hampir $20 \%$ dari seluruh jumlah penduduk di Indonesia adalah remaja. ${ }^{1}$ Badan Kependudukan dan Keluarga Berencana Nasional (BKKBN) menyebutkan pada tahun 2016, penduduk remaja berusia 10-24 tahun berjumlah 66,3 juta jiwa dari total penduduk (258,7 juta), sehingga satu di antara empat penduduk adalah remaja. ${ }^{2}$ Masa remaja merupakan masa yang unik, penting dan menyenangkan dalam pertumbuhan dan perkembangan kehidupan seseorang. ${ }^{3}$

Remaja adalah penduduk dalam rentang usia 10 hingga 19 tahun, ${ }^{4}$ sedangkan menurut $\mathrm{BKKBN}$, remaja berada pada rentang usia 10-24 tahun dan belum menikah. Tahapan usia remaja terbagi dalam 3 fase yaitu fase awal (12-14 tahun), menengah (15-17 tahun), dan akhir (18-21 tahun). ${ }^{5,6}$ Tanda bahwa masa remaja telah dimulai yaitu saat remaja mengalami pubertas kira-kira pada usia 10 sampai 13 tahun dan masa tersebut berakhir antara usia 18 dan 22 tahun yang disebut pula sebagai masa remaja awal dan akhir. ${ }^{7}$ Masa remaja awal (early adolescence) diperkirakan sama dengan masa sekolah menengah pertama, sedangkan masa remaja akhir (late adolescence) terjadi setelah seseorang berusia di atas 15 tahun.

Masa remaja awal dapat menjadi masa yang sulit bagi seorang remaja. ${ }^{3}$ Remaja mengalami berbagai perubahan baik fisik, kognitif, emosional, sosial, bahasa, karier, serta spiritual ketika memasuki masa pubertas. Perubahan-perubahan yang dialami oleh remaja dapat mempengaruhi cara seorang remaja bertindak dan mengambil keputusan. Pada masa pubertas, remaja memiliki kematangan fisik dan seksual, remaja juga mengalami tahapan menuju kemandirian sosial dan ekonomi, membangun identitas, akuisisi kemampuan (skill) untuk kehidupan masa dewasa serta kemampuan bernegosiasi (abstract reasoning). ${ }^{4}$

Pada masa remaja terjadi perubahan fisik dan seksual yang signifikan sehingga ketertarikan seksual terhadap lawan jenis cukup besar dan dorongan seksual juga berkembang. Remaja akan beradaptasi dengan perubahan tubuhnya serta belajar menerima perbedaan dengan individu lain, baik fisik maupun ideologi. ${ }^{2}$ Perubahan fisik yang pesat dan perubahan hormonal merupakan pemicu masalah kesehatan remaja yang serius. Timbulnya dorongan motivasi seksual yang tinggi menjadikan remaja rawan terhadap penyalahgunaan narkoba, berbagai penyakit dan masalah kesehatan reproduksi (kespro), serta kehamilan remaja dengan segala konsekuensinya yaitu hubungan seks pranikah, aborsi, Penyakit Menular Seksual (PMS), HIV/AIDS serta narkoba.

Hasil Survei Kesehatan Reproduksi Remaja Indonesia tahun 2007 dengan responden sekitar 10.830 tercatat sebanyak $27 \%$ remaja wanita dan $48 \%$ remaja pria minum-minuman beralkohol dalam 3 bulan terakhir. ${ }^{8}$ Data masalah penyimpangan perilaku remaja lainnya ditunjukkan dari hasil survey yang dilakukan oleh Badan Narkotika Nasional (BNN) pada tahun 2017 bahwa 3.376 .115 orang yang menggunakan narkoba berada pada kelompok usia 10-59 Tahun, dengan $24 \%$ pengguna adalah pelajar. ${ }^{9}$ Survei yang dilakukan oleh BKKBN pada tahun 2019 para remaja secara terbuka menyatakan pernah melakukan hubungan seksual pra nikah di Jabotabek (51 \%), Bandung (54 \%), Surabaya (47\%) dan Medan (52\%). ${ }^{10}$

Menurut data dari United Nations Development and Social Affair (UNDESA) tahun 2010, Indonesia termasuk Negara ke-37 dengan persentase pernikahan usia muda yang tinggi dan merupakan tertinggi kedua di ASEAN setelah Kamboja. ${ }^{11}$ Perilaku seksual pra nikah juga menyebabkan lebih dari 6 juta kasus kehamilan remaja setiap tahun serta hampir 4 juta aborsi dilakukan dengan tidak aman pada kalangan remaja, dimana setengah juta remaja bahkan hidup dengan HIV positif di wilayah Asia Pasifik. ${ }^{11}$

Beberapa hasil penelitian 
menunjukkan latihan keterampilan hidup (life skills) bagi remaja sangat besar pengaruhnya untuk membekali remaja dalam menjani kehidupannya, yang utamanya adalah untuk mengurangi dan mencegah munculnya permasalahan remaja. ${ }^{6}$ Beberapa keterampilan hidup yang penting yang diidentifikasi melalui metode Delphi adalah: pengambilan keputusan, penyelesaian masalah, berpikir kreatif/berpikir lateral, berpikir kritis/berkonsep, komunikasi yang efektif, hubungan interpersonal, kesadaran diri/perhatian, ketegasan, empati, mengatasi stres, trauma, dan kehilangan, serta ketangguhan. $^{12}$

UNICEF

mendefinisikan

keterampilan hidup sebagai perubahan perilaku atau pendekatan pengembangan perilaku yang dirancang untuk membantu remaja meningkatkan kemampuannya dalam mengatasi masalah yang dilihat dari pengetahuan, sikap dan keterampilan remaja terhadap suatu masalah. Keterampilan hidup seperti yang ditetapkan oleh WHO terdiri dari: 1) Keterampilan sosial berupa kesadaran diri, komunikasi yang efektif, dan keterampilan hubungan interpersonal; 2) Keterampilan berpikir berupa kemampuan berpikir kreatif, berpikir kritis, pengambilan keputusan, dan pemecahan masalah; 3) Keterampilan emosional berupa empati, mengatasi stres, dan mengatasi emosi. ${ }^{13}$ Bila dirinci maka ada sepuluh keterampilan hidup yang dapat mendukung remaja dalam mengatasi permasalahannya yang tergambar dalam pengetahuan, sikap dan keterampilannya.

Hasil penelitian mengungkapkan bahwa kemampuan remaja dalam menangani masalah-masalah yang dihadapinya dipengaruhi oleh beberapa faktor seperti kepribadian mereka, dukungan psikososial dari lingkungan (yang mencakup orang tua, guru, dan teman sebaya) serta keterampilan hidup yang mereka miliki. ${ }^{14}$ Penelitian lain menunjukkan bahwa pelatihan keterampilan hidup melalui penanaman pendidikan kecakapan hidup akan membantu remaja kita untuk mengatasi kesulitan-kesulitan dalam hidup. ${ }^{15}$

Penelitian lainnya membuktikan bahwa dengan pelatihan keterampilan hidup yang terstruktur dan berkelanjutan bersama dengan konseling membantu dalam mengembangkan perubahan positif di antara remaja dengan perilaku bermasalah. ${ }^{16}$ Pelatihan ini juga membantu remaja untuk mengembangkan hubungan persahabatan dengan guru, teman sebaya dan orang tua. Hakikatnya dengan life skills yang dimilikinya, remaja akan hidup lebih tangguh, kuat, disiplin, religius, bernurani dan berkarakter, sehingga remaja semakin sehat dan terhindar dari penyalahgunaan narkoba serta HIV/AIDS.

Berdasarkan uraian di atas dapat dikatakan bahwa keterampilan hidup sangat penting dalam meningkatkan kemampuan remaja dalam menghindari bahaya narkoba dan HIV/AIDS. Petugas kesehatan di komunitas dituntut untuk dapat merancang program penyelesaian masalah kesehatan pada remaja, salah satunya melalui pendidikan keterampilan hidup bagi remaja. Penelitian akan dilakukan di dua sekolah menengah pertama di wilayah Cipayung Jakarta Timur. Hal ini karena lokasi sekolah juga sangat mudah diakses dan dekat dengan fasilitas pelayanan umum seperti pusat perbelanjaan, bioskop, karaoke serta tempat makan yang bisa dijadikan tempat bagi para pengedar melakukan transaksi narkoba ataupun perilaku seksual berisiko. Pada penelitian ini, peneliti akan mengukur bagaimana pengaruh latihan keterampilan hidup terhadap kemampuan remaja dalam menghindari narkoba dan HIV/AIDS.

\section{Metode}

Penelitian ini menggunakan metodologi quasi experiment with control group design. Penelitian ini dilakukan di dua Sekolah Menengah Pertama Negeri (SMPN) di Wilayah Cipayung, Jakarta Timur. SMPN $\mathrm{X}$ sebagai kelompok intervensi dan SMPN Y sebagai kelompok kontrol. Populasi pada penelitian ini adalah seluruh siswa SMP (laki-laki dan perempuan) yang ada di 
sekolah tempat penelitian. Sampel penelitian adalah seluruh siswa kelas VII dan VIII, siswa dengan kriteria inklusi yaitu siswa berusia 12-15 tahun, mampu berkomunikasi dengan baik menggunakan bahasa Indonesia dan bersedia menjadi responden. Kriteria eksklusi pada penentuan sampel adalah tidak bersedia menjadi responden dan sedang dalam keadaan sakit. Teknik sampling menggunakan simple random sampling dengan jumlah sampel sebanyak 66 orang.

Tehnik pengumpulan data dilakukan dengan langkah-langkah sebagai berikut: 1) Melakukan perizinan pada pihak sekolah; 2) Menentukan partisipan dengan menyebarkan kuesioner ke seluruh siswakelas VII dan VIII dan memilihnya yang sesuai dengan kriteria inklusi, dibantu oleh guru; 3) Melakukan inform consent, pernyataan bersedia menjadi partisipan yang juga ditanda tangani oleh orangtua; 4) Menyediakan obat-obatan dan alat pertolongan pertama terhadap kecelakaan yang terjadi di sekolah saat dilakukan pengumpulan data; 5) Melakukan pelatihan kepada enumerator yang akan membantu proses pengumpulan data; 6) Pengumpulan data melibatkan pihak guru UKS, pihak puskesmas ataupun enumerator yang sudah dilatih terlebih dahulu; 7) Melakukan pengumpulan data pre test kepada kelompok kontrol dan kelompok intervensi dengan menggunakan kuesioner sebelum dilakukan pelatihan; 8) Melakukan pelatihan keterampilan hidup kepada kelompok intervensi dengan menggunakan modul. Para siswa yang menjadi partisipan dibagi menjadi tiga kelompok kecil, terdiri dari 11 orang dengan 1 orang guru pendamping yang diberikan latihan.

Kelompok intervensi adalah kelompok yang mendapat perlakuan berupa pemberian modul dan buku catatan harian serta pelatihan keterampilan hidup. Kelompok kontrol adalah kelompok yang hanya diberikan modul dan buku catatan harian tanpa diberikan pelatihan keterampilan hidup. Pelatihan keterampilan hidup (keterampilan sosial, keterampilan berpikir dan keterampilan emosi) dilakukan sebanyak 8 kali atau 8 sesi yang terdiri dari latihan kesadaran diri, latihan komunikasi efektif, latihan menjalin hubungan interpersonal, latihan berpikir kritis, pemecahan masalah dan berpikir kreatif, latihan pengambilan keputusan, latihan empati, latihan mengatasi stres, dan latihan mengatasi emosi dan marah. Pada modul latihan keterampilan yang diberikan kepada siswa terdapat satu halaman yang berisikan lembar pernyataan bahwa orangtua telah membaca isi modul dan mengijinkan anaknya mengikuti kegiatan penelitian ini.

Pengumpulan data dilakukan sebanyak dua kali dengan menggunakan kuesioner. Pengambilan data pertama (pre test) dilakukan di awal pertemuan pada masing-masing kelompok. Pengambilan data kedua (post test) pada kelompok intervensi dilakukan setelah diberikan modul dan paket pelatihan selama dua bulan. Pengambilan data kedua (post test) pada kelompok kontrol dilakukan dua bulan setelah diberikan modul.

Analisis data pada penelitian ini dilakukan secara univariat dan bivariat. Analisis univariat digunakan untuk mendeskripsikan setiap variabel penelitian dengan melihat distribusi dan frekuensi setiap variabel. Analisis bivariat digunakan untuk melihat perbedaan kemampuan remaja dalam menghindari HIV/AIDS pada kelompok intervensi dan kelompok kontrol menggunakan dependent t-test yaitu uji statistic yang dilakukan untuk mengetahui perbedaan pengetahuan, sikap serta keterampilan remaja sebelum dan sesudah diberikan latihan dan independent t-test yaitu uji statistic yang dilakukan pada kelompok intervensi dan kelompok kontrol untuk mengetahui perbedaan pengetahuan, sikap serta keterampilan remaja sebelum dan sesudah diberikan latihan. 


\section{Hasil}

Tabel 1. Distribusi Frekuensi Responden berdasarkan Karakteristik dan Aktivitas di Luar Jam Sekolah

\begin{tabular}{|c|c|c|c|c|c|}
\hline \multirow{2}{*}{ Variabel } & \multirow{2}{*}{ Kategori } & \multicolumn{2}{|c|}{ Intervensi } & \multicolumn{2}{|c|}{ Kontrol } \\
\hline & & $\mathbf{n}$ & $\%$ & $\mathbf{n}$ & $\%$ \\
\hline \multirow[t]{2}{*}{ Jenis kelamin } & Laki-laki & 16 & 48,5 & 10 & 30,3 \\
\hline & Perempuan & 17 & 51,5 & 23 & 69,7 \\
\hline \multirow[t]{3}{*}{ Agama } & Islam & 30 & 90,9 & 24 & 72,7 \\
\hline & Kristen & 1 & 3,0 & 7 & 21,2 \\
\hline & Hindu & 2 & 6,1 & 2 & 6,1 \\
\hline \multirow[t]{4}{*}{ Suku } & Betawi & 8 & 24,2 & 8 & 24,2 \\
\hline & Sunda & 7 & 42,4 & 3 & 9,1 \\
\hline & Batak & 14 & 12,1 & 13 & 39,4 \\
\hline & Bali & 4 & 21,2 & 9 & 27,3 \\
\hline \multirow[t]{5}{*}{ Aktifitas di luar jam sekolah } & 1 Kegiatan & 10 & 30,3 & 6 & 18,2 \\
\hline & 2 kegiatan & 4 & 12,1 & 1 & 3,0 \\
\hline & 3 kegiatan & 7 & 21,2 & 8 & 24,2 \\
\hline & 5 kegiatan & 5 & 15,2 & 9 & 27,3 \\
\hline & 6 kegiatan & 7 & 21,2 & 9 & 27,3 \\
\hline \multirow[t]{2}{*}{ Dukungan Sosial Pada remaja } & Dukungan baik & 21 & 63,6 & 17 & 51,5 \\
\hline & Dukungan Kurang baik & 12 & 36,4 & 16 & 48,5 \\
\hline
\end{tabular}

Tabel 2. Distribusi Perbedaan Nilai Pre dan Post test pada kelompok Intervensi

\begin{tabular}{ccccccc}
\hline Variabel & Mean & SD & $\mathbf{9 5 \%}$ CI & T & p-value & N \\
\hline Pengetahuan & & & & & & \\
$\quad$ Pre Test & 5,61 & 0,508 & $-3,881$ & $-11,644$ & 0,001 & 33 \\
$\quad$ Post Test & 8,91 & 0,415 & $-2,725$ & & & \\
Sikap & & & & & & \\
$\quad$ Pre Test & 7,61 & 1,456 & $-1,867$ & $-4,706$ & 0,001 & 33 \\
$\quad$ Post Test & 8,91 & 0,879 & $-0,706$ & & & \\
Keterampilan & & & & & & \\
$\quad$ Pre Test & 29,79 & 2,945 & $-6,548$ & $-5,952$ & 0,001 & 33 \\
$\quad$ Post Test & 34,67 & 3,722 & $-3,209$ & & & \\
\hline
\end{tabular}

Tabel 3. Distribusi Perbedaan Nilai Pre dan Post test pada kelompok Kontrol

\begin{tabular}{ccccccc}
\hline Variabel & Mean & SD & $\mathbf{9 5 \%}$ CI & T & p-value & N \\
\hline Pengetahuan & & & & & & \\
Pre Test & 6,55 & 0,938 & $-0,362$ & $-0,683$ & 0,500 & 33 \\
$\quad$ Post Test & 6,64 & 0,783 & $-0,180$ & & & \\
Sikap & & & & & & \\
$\quad$ Pre Test & 7,24 & 0,751 & 0,415 & $-0,571$ & 0,572 & 33 \\
$\quad$ Post Test & 7,33 & 0,854 & $-0,233$ & & & \\
Keterampilan & & & & & & 33 \\
Pre Test & 23,45 & 4,542 & $-0,415$ & $-0,349$ & 0,730 & \\
Post Test & 23,52 & 3,898 & $-0,293$ & & & \\
\hline
\end{tabular}

Pada tabel 1 dapat dilihat bahwa pada kelompok intervensi umur responden adalah umur 13 tahun sebanyak $14(42.4 \%)$ siswa dan umur 14 tahun sebanyak $11(33.3 \%)$ siswa. Pada kelompok kontrol umur 13 tahun sebanyak $15(45.5 \%)$ siswa dan umur 14 tahun sebanyak 13 (39.4\%) siswa.

Jenis kelamin pada kelompok intervensi hampir sama yaitu ada 17 siswa dan laki-laki 16 siswa, sedangkan pada kelompok kontrol lebih banyak perempuan yaitu $23(69.7 \%)$ siswa dan sisanya (10 siswa) laki-laki. Agama terbanyak responden yaitu Islam $30(90.9 \%)$ siswa pada kelompok intervensi dan 24 (72.7\%) siswa pada kelompok kontrol. Suku terbanyak pada kedua kelompok yaitu Betawi yaitu 14 (30.3\%) siswa pada 
Tabel 4. Analisis Perbedaan Nilai Pengetahuan, Sikap dan Keterampilan pada Kelompok Intervensi dan Kontrol

\begin{tabular}{lcccccc}
\hline Variabel & N & Mean & SD & 95\% CI & F & P value \\
\hline Pengetahuan & & & & & & \\
$\quad$ Intervensi & 33 & 8,91 & 0,879 & $1,863-2,682$ & 0,690 & 0,000 \\
$\quad$ Kontrol & 33 & 6,64 & 0,783 & & & \\
Sikap & & & & & & \\
$\quad$ Intervensi & 33 & 8,45 & 1,301 & $0,580-1,662$ & 890 & 0,000 \\
$\quad$ Kontrol & 33 & 7,33 & 0,854 & & & \\
Keterampilan & & & & & & \\
$\quad$ Intervensi & 33 & 34,67 & 3,722 & $9,277-13.026$ & 0,362 & 0,000 \\
$\quad$ Kontrol & 33 & 23,52 & 3,898 & & & \\
\hline
\end{tabular}

kelompok intervensi dan $8(24.2 \%)$ siswa pada kelompok kontrol. Pada tabel 1 juga terlihat bahwa semua responden memiliki minimal satu aktifitas di luar jam sekolah. Responden pada kelompok intervensi dan kelompok kontrol mayoritas memiliki dukungan sosial baik dalam menghindari HIV/AIDS yaitu 21(63.6\%) siswa pada kelompok intervensi dan 17 (51.5\%) siswa pada kelompok kontrol.

Tabel 2 menunjukkan bahwa pada kelompok intervensi, rata-rata nilai pengetahuan pre test adalah 5,61 dan post test 8,91 dengan $p$ value 0,001 sehingga dapat disimpulkan bahwa ada perubahan yang siknifikan pada nilai pengetahuan. Pada variabel sikap, hasil analisis menunjukkan bahwa rata-rata nilai sikap pre test adalah 7,61 dan post test 8,91 dengan $p$ value 0.001 sehingga dapat disimpulkan bahwa ada perubahan yang signifikan pada nilai sikap. Pada variabel keterampilan menghindar dari HIV/AIDS menunjukkan bahwa rata-rata nilai keterampilan pre test adalah 29,79 dan post test 34,67 dengan $p$ value 0,001 sehingga dapat disimpulkan bahwa ada perubahan yang signifikan pada nilai keterampilan.

Tabel 3 menunjukkan bahwa pada kelompok kontrol, rata-rata nilai pengetahuan pre test adalah 6.55 dan post test 6.64 dengan $p$ value 0.500 sehingga dapat disimpulkan bahwa tidak ada perubahan yang signifikan pada nilai pengetahuan. Pada variabel sikap, hasil analisis menunjukkan bahwa rata-rata nilai sikap pre test adalah 7.24 dan post test 7.33 dengan $p$ value 0.572 sehingga dapat disimpulkan bahwa tidak ada perubahan yang signifikan pada nilai sikap. Pada variabel keterampilan menghindar dari HIV/AIDS menunjukkan bahwa rata-rata nilai keterampilan pre test adalah 23.45 dan post test 23.52 dengan $p$ value 0.730 sehingga dapat disimpulkan bahwa tidak ada perubahan yang signifikan pada nilai keterampilan.

Hasil analisis pada tabel 3 menunjukkan bahwa terdapat perbedaan yang signifikan pada variabel pengetahuan antara kelompok intervensi dan kelompok kontrol dengan $p$ value 0.000 . Pada variable sikap, terdapat perbedaan yang signifikan antara kelompok intervensi dan kelompok kontrol dengan $p$ value 0.000 . Pada variabel keterampilan juga terdapat perbedaan yang signifikan antara kelompok intervensi dan kelompok kontrol dengan nilai $p$ value 0.000 .

\section{Pembahasan}

Hasil penelitian ini menunjukkan bahwa umur pada kelompok intervensi adalah umur 13 tahun sebanyak 14 orang $(42,4 \%)$, dan umur 14 tahun ada 11 orang $(33,3 \%)$, sedangkan umur pada kelompok kontrol umur 13 tahun sebanyak 15 orang $(45,5 \%)$ dan umur 14 tahun sebanyak 13 orang $(39,4 \%)$. Batasan usia remaja adalah masa remaja awal (early adolescence) diperkirakan sama dengan masa Sekolah Menengah Pertama (SMP), sedangkan masa remaja akhir (late adolescence) terjadi setelah seseorang berusia di atas 15 tahun. $^{7}$ Rentang umur responden 13-15 tahun termasuk dalam masa remaja dengan 
katagori remaja fase awal. ${ }^{7,10}$

Masa remaja awal dapat menjadi masa yang sulit bagi seorang remaja. ${ }^{3}$ Remaja mengalami berbagai perubahan baik fisik, kognitif, emosional, sosial, bahasa, karier, serta spiritual ketika memasuki masa pubertas. Perubahan-perubahan yang dialami oleh remaja dapat mempengaruhi cara seorang remaja bertindak dan mengambil keputusan. Pada masa pubertas, remaja memiliki kematangan fisik dan seksual, remaja juga mengalami tahapan menuju kemandirian sosial dan ekonomi, membangun identitas, akuisisi kemampuan (skill) untuk kehidupan masa dewasa serta kemampuan bernegosiasi (abstract reasoning). ${ }^{17}$

Pada masa remaja terjadi perubahan fisik dan seksual yang signifikan sehingga ketertarikan seksual terhadap lawan jenis cukup besar dan dorongan seksual juga berkembang. Menurut Erikson, remaja akan beradaptasi dengan perubahan tubuhnya serta belajar menerima perbedaan dengan individu lain, baik fisik maupun ideologi. ${ }^{3}$ Perubahan fisik yang pesat dan perubahan hormonal merupakan pemicu masalah kesehatan remaja yang serius. Timbulnya dorongan motivasi seksual yang tinggi menjadikan remaja rawan terhadap penyalahgunaan narkoba, berbagai penyakit dan masalah kesehatan reproduksi, serta kehamilan remaja dengan segala konsekuensinya yaitu hubungan seks pranikah, aborsi, Penyakit Menular Seksual (PMS), dan HIV/AIDS.

Hasil penelitian ini menunjukkan bahwa pada kelompok intervensi terdapat perbedaan yang signifikan pada nilai pre dan post test pada variabel pengetahuan, sikap dan keterampilan hidup. Sedangkan pada kelompok kontrol tidak ada perbedaan yang signifikan pada nilai pre dan post test pada variabel pengetahuan, sikap dan keterampilan hidup. Hasil analisa lebih lanjut menyimpulkan bahwa pelatihan memberikan pengaruh yang signifikan terhadap pengetahuan, sikap dan keterampilan hidup siswa dalam menghindari HIV/AIDS.
Hasil penelitian ini sesuai dengan penelitian sebelumnya yang membuktikan bahwa dengan pelatihan keterampilan hidup yang terstruktur dan berkelanjutan bersama dengan konseling membantu dalam mengembangkan perubahan positif di antara remaja dengan perilaku bermasalah. ${ }^{14}$ Pelatihan ini juga membantu remaja untuk mengembangkan hubungan persahabatan dengan guru, teman sebaya dan orang tua. Hakikatnya dengan life skills yang dimilikinya, remaja akan hidup lebih tangguh, kuat, disiplin, religius, bernurani dan berkarakter, sehingga remaja semakin sehat dan terhindar dari HIV/AIDS.

Kemampuan remaja dalam menangani masalah-masalah yang dihadapinya dipengaruhi oleh beberapa faktor seperti kepribadian mereka, dukungan psikososial dari lingkungan (yang mencakup orang tua, guru, dan teman sebaya) serta keterampilan hidup yang mereka miliki. ${ }^{14}$ Hal ini menguatkan jika remaja memiliki keterampilan hidup yang baik, maka mereka akan dapat terhidar dari penyimpangan perilaku seksual pranikah yang berisiko terhadap HIV/AIDS. Pelatihan keterampilan hidup melalui penanaman pendidikan kecakapan hidup akan membantu remaja kita untuk mengatasi kesulitan-kesulitan dalam hidup. ${ }^{15}$

\section{Kesimpulan}

Hasil penelitian menunjukkan bahwa terdapat perbedaan yang signifikan pada pengetahuan, sikap dan keterampilan antara kelompok intervensi yang mendapat perlakuan berupa pemberian modul dan buku pemantauan dengan disertai pelatihan keterampilan hidup dibandingkan dengan kelompok kontrol yang hanya diberikan modul dan buku pemantauan tanpa disertai pelatihan. Pelatihan keterampilan hidup remaja dapat digunakan sebagai salah satu intervensi dalam upaya mencegah HIV AIDS pada remaja.

\section{Daftar Pustaka}

1. Kemenkes RI [Internet]. Menkes: Remaja Indonesia Harus Sehat. Kemkes, 2018. [cited 15 Maret 2019] Available from 
https://www.kemkes.go.id/ article/view /18051600001/menkes-remaja-indonesia-harus -sehat.html.

2. Kusumaryani M. Brief notes: Prioritaskan kesehatan reproduksi remaja untuk menikmati bonus demografi. Lemb Demogr FEB UI; 2017:1-6.

3. Covelli, Grace. [Internet]. Developmental Characteristics of Early Adolescence. Healthfully, 2017. [cited 15 Maret 2019]. Available from https://healthfully.com/165727-developmentalcharacteristics-of-early-adolescence.

4. WHO. Angka Kematian Bayi Baru Lahir; 2015.

5. World Health Organization (WHO). [Internet]. Region SA: Strategic Guidance on Accelerating Actions for Adolescent Health in South-East Asia Region 2018-2022. WHO Library Cataloguing-in-Publication data; 2018. [cited 15 Maret 2019]. Available from https://apps.who.int/iris/bitstream/handle/1066 5/274312/9789290226475-eng.pdf?sequence $=1$ \&isAllowed=y.

6. Tri Ermayani [Internet]. Pembentukan Karakter Remaja Melalui Keterampilan Hidup. Jurnal Pendidikan Karakter; 2015. [cited 15 Maret 2019]. Available from https://journal.uny.ac.id/index.php/jpka/article/ view/8618

7. Santrock J. Adolescence. 17th ed. New York: McGraw-Hill; 2019.

8. Suryani, dkk. [Internet]. Upaya Pencegahan Penyalahgunaan Narkoba Dan Seks Bebas Serta Peningkatan Kemampuan Koping Remaja Berbasis Kelompok Sebaya di SMP dan SMA di Jatinangor. J Apl Ipteks untuk Masy; 2014:Vol. 3. [cited 15 Maret 2019]. Avaliable from http://jurnal.unpad.ac.id/dharmakarya/article/vi ew/8357.

9. BNN. Survei Nasional Penyalahgunaan Narkoba Di 34 Provinsi Tahun 2017. Pusat Penelitian Data Dan Informasi Badan Narkotika Nasional Republik Indonesia; 2017.

10. BKKBN. [Internet]. Perkawinan Anak di
Indonesia Masih Tinggi. BKKBN; 2019. [cited 17 Maret 2020] Available from https://www.bkkbn.go.id/detailpost/ perkawinan-anak-di-indonesia-masih-tinggi

11. Kemenkes RI. Pedoman Pelayanan Kesehatan Reproduksi Terpadu Di Tingkat Pelayanan Kesehatan Dasar. 2nd ed. Jakarta: Kemenkes; 2015.

12. Goel, Anu. [Internet]. Life skills in adolescence. Merinews.; 2017. [cited 2 Februari 2019]. Available from http://www.merinews.com/article/life-skills-inadolescence/15922809. shtml.

13. Kumar Jitender \& Chhabra A. [Internet]. Life Skill Education for Adolescents: Coping with Challenges. FEB-MARCH, Vol-I, Issue-II. Scholar Research Journal for Humanity Sience an English Language; 2014. [cited 15 Maret 2019]. Available from www.srjis.com

14. Srivastava, Garima. [Internet]. The importance of life skills for adolescents. White Swan Foundation; 2015. [cited 15 Maret 2019]. Available from https://www.whiteswanfoundation.org/life-stag es/adolescence/the-importance-of-teaching-you r-adolescent-life-skill

15. Aparna N1 and Raakhee.A.S. [Internet]. Life Skill Education For Adolescents: Its Relevance And Importance. GESJ Educ Sci Psychol; 2011;No.2(19). [cited 17 Februari 2019]. Available from gesj.internet-academy.org

16. Radhakrishnan, Nair. [Internet]. Life Skills Education: A Strategy for Handling Adolescents' Risk Behavior. IOSR Journal Of Humanities And Social Science (IOSR-JHSS) Volume 21, Issue 7, Ver. V (July. 2016) PP 92-99 2016. [cited 17 Februari 2019]. Available from www.iosrjournals.org

17. WHO. [Internet] Adolescent Development; Topics at Glance. WHO; 2015. [cited 15 Maret 2019]. Available from https://www.who.int/maternal_child_adolescen t/topics/en/. 